\title{
USE OF SPONGOFACIES AS A PROXY FOR RIVER-LAKE PALEOHYDROLOGY IN QUATERNARY DEPOSITS OF CENTRAL-WESTERN BRAZIL
}

\author{
MAURO PAROLIN \\ Laboratório de Estudos Paleoambientais, Faculdade Estadual de Ciências e Letras de Campo Mourão, \\ Rua Chafic B. Maluf, 21, 87300-170, Campo Mourão, PR, Brazil.mauroparolin@gmail.com \\ CECÍLIA VOLKMER-RIBEIRO \\ Museu de Ciências Naturais, FZBRS, Cx. P. 1188, 90001-970, Porto Alegre, RS, Brazil.cvolkmer@fzb.rs.gov.br \\ JOSÉ CÂNDIDO STEVAUX \\ Programa de Pós-Graduação em Análise Geoambiental, UnG, Pr. Teresa Cristina, 1, 07023-070, Guarulhos, SP, Brazil. \\ jstevaux@prof.ung.br
}

\begin{abstract}
Sediments obtained by vibrocoring from Samambaia Lake (22 $36^{\prime}$ 'S / 53 $23^{\circ}$ 'W) in Taquarussu, Mato Grosso do Sul State, Brazil, were dated using thermoluminescence. Grain size and organic content analysis were performed, and the freshwater sponge spicules present in the sediments were identified. The age of sediments ranged between TL 4,350 \pm 210 and TL 32,740 \pm 163 years BP. Spicules of the sponges Dosilia pydanieli, Metania spinata, Radiospongila amazonensis, Corvospongilla sp. and Oncosclera sp. were found. Analyses suggest an alternation of lotic and lentic phases, in agreement with earlier lines of evidence regarding the existence of paleodrainage in the region during the Late Pleistocene to the MidHolocene, as well as previously described paleoclimatic conditions. This work reinforces the reliability of the use of freshwater sponge spicules as proxy data in the proposition of paleoenvironmental reconstructions. The term spongofacies is introduced for the sedimentary sequences in which spicules of freshwater sponge species predominate and indicate specific paleoenvironmental conditions.
\end{abstract}

Key words: Lentic sediments, siliceous spicules, freshwater sponges, paleoenvironmental reconstructions.

RESUMO - Sedimentos recuperados através de perfuração com vibro-core na Lagoa Samambaia (22 $\left.36^{\prime} \mathrm{S} / 53^{\circ} 23^{\prime} \mathrm{W}\right)$, Taquarussú, Mato Grosso do Sul, Brasil, foram datados por termoluminescência. Análises granulométricas e de conteúdo de matéria orgânica foram levadas a efeito, bem como a identificação taxonômica das espículas de esponjas detectadas nos sedimentos. A idade dos sedimentos variou entre TL 4,350 \pm 210 and TL 32,740 \pm 163 anos BP. Foram encontradas espículas das esponjas Dosilia pydanieli, Metania spinata, Radiospongilla amazonensis, Corvospongilla sp. e Oncosclera sp. As análises sugerem uma alternância de fases lóticas e lênticas, em concordância, tanto com evidências anteriores que indicavam a existência de uma paleodrenagem na região, do fim do Pleistoceno ao Holoceno médio, como com condições paleoclimáticas previamente descritas. O trabalho reassegura a viabilidade do uso das espículas das esponjas como um dado proxi em proposições de reconstruções paleoambientais. O termo espongofacies é introduzido para as seqüências sedimentares nas quais espículas de espécies de esponjas continentais predominam e indicam condições paleoambientais específicas.

Palavras-chave: Sedimentos lênticos, espículas silicosas, esponjas de água doce, reconstrução paleoambiental.

\section{INTRODUCTION}

Palynomorphs are normally the most common proxy data used in the Quaternary continental reconstructions (Bradley, 1985). However, in humid tropical areas, the intensity of weathering normally oxidizes soil, and in many cases, organic material is totally destroyed (Stevaux, 1994). In these cases, biogenic silica in the form of phytoliths, diatom frustules and sponge spicules are fundamental for studies in these areas, since these components are less susceptible to chemical weathering.

Concerning silicophytoliths, the pioneer works of Bertoldi de Pomar $(1970,1972,1975)$ focused strictly on surface sediments and on suspended sediments of the Paraná River,
Argentina. More recent papers on this subject in South America are restricted to sub-tropical and temperate climate areas of the Argentina (e.g., Osterrieth, 2001). The presence of phytoliths and some spicule morphotypes of fluvial deposit in the Uruguay basin are reported as well by Zucol et al. (2005).

Sponge spicules offer indicator advantage when compared with the traditional indicators, because their siliceous composition can be preserved in coarser sediment such as sand. Sponge spicules also resist both remobilization processes and weathering exposure. Afterward, laboratory processes are rapid and relatively inexpensive when compared with pollen and other proxy data. All known freshwater sponges have skeletons composed of siliceous 
$\left(\mathrm{SiO}_{2}\right)$ noncrystalline spicules organically glued together by spongin. The identification of these sponges is established based on the spicule categories particular to each species. As these hard siliceous spicules are preserved in river and lake sediments upon the death of the sponge, they stand for the ecological signature particular to each species and are thus, a valuable tool in the interpretation of paleoenvironmental conditions. Once spicules are detected in the sedimentary cores, the analysis of their taxonomy, amount in the sediment, developmental stage, presence of gemmoscleres, i.e., spicules that cover gemmules, and shape integrity allow for the identification of a past lotic or lentic environment, and site of origin or transport, as well as the climate and precipitation regime. Of particular importance is the detection of gemmoscleres, since the identification of freshwater sponge species is based primarily upon such spicules (Penney \& Racek, 1968; Volkmer-Ribeiro \& Pauls, 2000; Volkmer-Ribeiro, 2007). Gemmules are resistant bodies especially produced by freshwater sponges to overcome enrironmental unfavorable conditions. The presence of freshwater sponge spicules in a sediment, first of all, obviously indicates an aquatic environment, but their gemmoscleres, besides allowing for species identification, point to seasonal changes in temperature and water levels, depending on the geographical area under consideration (Harrison, 1988; Frost, 1991; Volkmer-Ribeiro, 2007; Volkmer-Ribeiro et al. 1999).

Studies on freshwater sponge spicules in Quaternary paleoenvironmental reconstructions in the northern hemisphere date from several decades and have all evinced the occurrence of extant species (Racek 1970; Hall \& Herrmann, 1980; Harrison et al., 1979; Harrison 1988; Gaiser et al., 2004). Concerning Brazilian Quaternary continental reconstructions also, only extant freshwater sponge species have been detected. Sifeddine et al. (1994, 2001), using infrared, geochemical and petrographic organic analyses, detected a regional climate with five stages of succession of humid and dry periods signaled particularly by gemmoscleres of the sponge Corvomeyenia thumi present in lacustrine deposits from the Carajás Region, Pará State, Brazil. Cordeiro et al. (1997) also demonstrated that the high amount of spicules of Corvomeyenia thumi in sediments recovered from lacustrine deposits at the Carajás Region, indicated a dry period from 6,800 to 4,000 years BP. Volkmer-Ribeiro et al. (2006, 2007), working with sponge spicules recovered from coastal freshwater bodies, detected particular aspects of coastal evolution in the Atlantic southern border of South America. Parolin et al. (2007) detected past flooding pulses with peat formation between 4,610-4,010 years BP, based on the identification of spicules of four different species present in sediments recovered in the Upper Paraná River, Mato Grosso do Sul State, Brazil. In this paper, we report the methodology used for the utilization of sponge spicules as proxy data in paleoenvironmental characterization of lacustrine deposits of southeast Mato Grosso do Sul State, Brazil and the corresponding results.

With respect to older sediments, Pisera \& Sáez (2003) produced a remarkable paleoenvironmental interpretation based on the presence of spicules of a new species of freshwater sponge in the Late Miocene Quillagua Formation sediments (N Chile).

The facies or sedimentary facies concept in geosciences was introduced by Gressly (1830, in Stevaux, 1986) as the set of lithological characteristics of a rocky formation by which one can identify its depositional environment. During the 1970 's the term facies was intensively used by sedimentologists, especially in petroleum research. Selley (1970) proposed that a facies would identify and determine the sedimentary process and not exactly a depositional environment which, in turn, would be identified by a facies association. He defined five attributes for a sedimentary facies: geometry, lithology, sedimentary structures, paleocurrent pattern, and fossils. Lately, the term has been applied with different objectives in geosciences: palynological studies (palynofacies), in metamorphic petrology (metamorphic facies), in pedology (alteration facies) and others. In this paper, the term spongofacies is defined as a depositional section with predominance of continental sponge spicules of a single species or of a sponge assemblage that allows paleoenvironmental indentification. The characteristics taken into consideration, besides the specific identification offered by the spicules, are the amount, state of formation and preservation, as well as the depositional condition.

\section{STUDY SITE}

Stevaux (1994), when describing the terraces along the right bank of the Paraná River in the region of Taquarussu (southeast Mato Grosso do Sul State, Brazil), noted the presence of sponge spicules in the lake deposits and pointed to their increase in percentage terms from the base to the top of the deposits. In this same region the author defined four geomorphological units associated with the Upper Paraná River valley (Figure 1): Porto Rico Unit, the highest one formed by Cretaceous sandstone of the Caiuá Formation covered by sandy soils and colluvium deposits; Paraná River Unit, represented by the active alluvial plain of the Paraná River $(<6,000$ years BP, Stevaux, 2000); Fazenda Boa Vista Unit, an 8- to 9-m alluvial terrace which formed Late Pleistocene (40,000 - 10,000 years BP, Stevaux \& Santos, 1998) deposits of the ancient Paraná River; and Taquarussu Unit - a sandy, reddish flattened surface $(120,000-64,000$ years BP, Sallun, 2007) characterized by the presence of hundreds of small semi-circular, irregular lakes formed probably by pseudokarstic processes (Stevaux, 1994).The author reported that the level of the lakes, detected in the aerial surveys of 1953 and 1965 (and also as anecdotal evidence from the region suggests), was lower than at present, the majority being practically dry. This fact was attributed to the removal of the plant coverage which took place from the 1960 s on, causing reduction in water plant absorption and consequently rising of the piezometric regional surface. Studies based on the stratigraphy, palynology and the dating of the absolute age of the sediments, furnished the first paleo-climatic data on the region with the succession of four events: i) the 


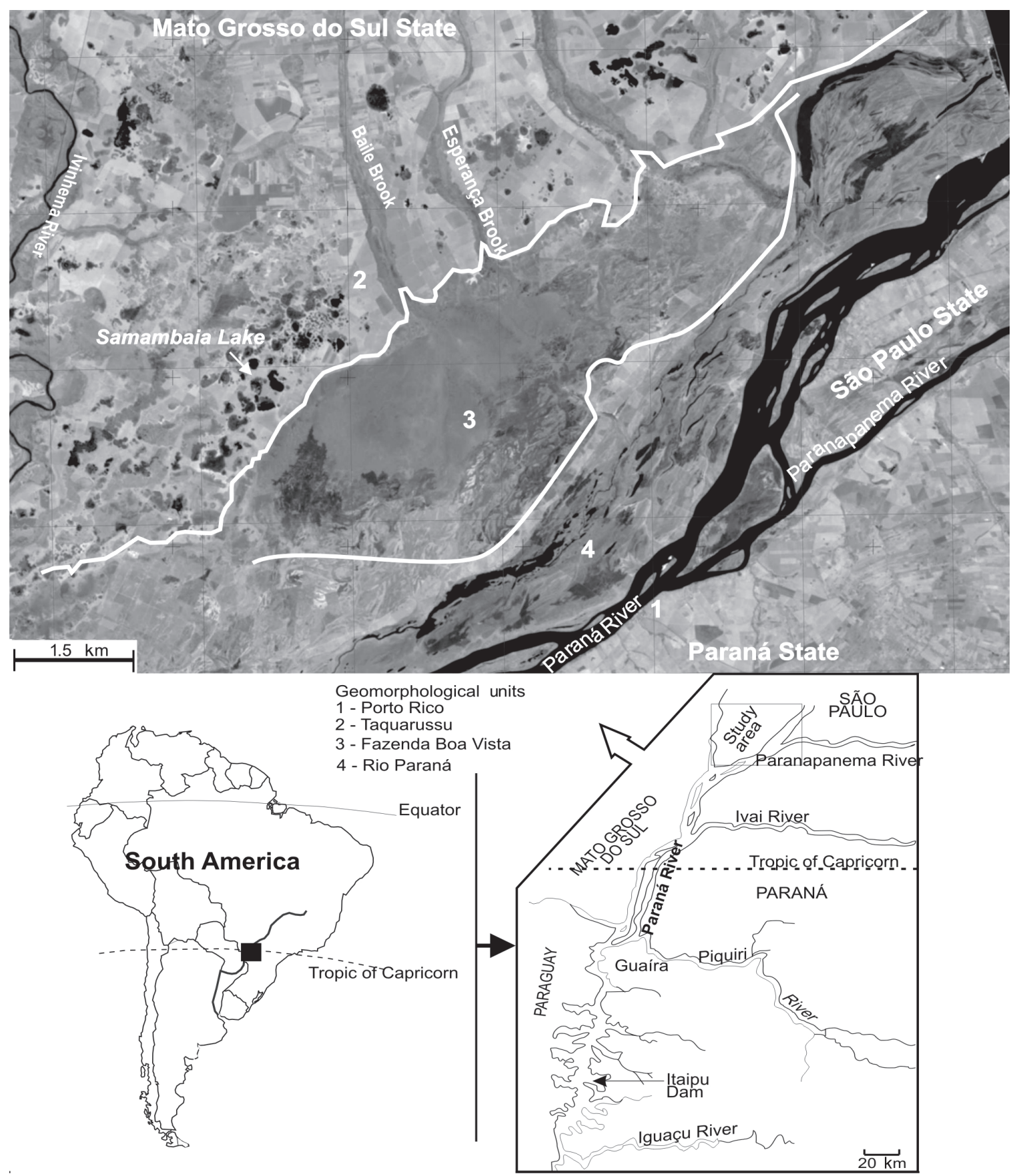

Figure 1. Maps and satellite image of the study area showing the regional geomorphological units and the Samambaia Lake.

first dry period, in the Late Pleistocene around 40,000 years BP; ii) the first humid period, in the Mid-Holocene between 7,500 and 3,500 years BP; iii) a short dry period, in the Upper Holocene between 3,500 and 1,500 years BP; and iv) the present humid period, from 1,500 years BP until the present (Stevaux 2000). Lately, Parolin \& Stevaux (2004) extended this short dry period up to 4,600 years BP based on eolic activity and dune formation over the Taquarussu surface.

Samambaia Lake, one of the largest water bodies of the Taquarussu Geomorphological Unit (22 $36^{\prime}$ 'S and $\left.53^{\circ} 23^{\prime} \mathrm{W}\right)$, is irregular in shape, covers $800,000 \mathrm{~m}^{2}$, and contains a small island in its southwest portion (Figure 2). The region currently has a tropical humid climate, with an annual average temperature of $24^{\circ} \mathrm{C}$ and an annual rainfall of 1,250 to 1,550 $\mathrm{mm}$. According to Nimer (1989), precipitation is not well distributed over the course of the year, the seasonal regime being typically tropical, with an accentuated maximum in summer and a minimum in winter. During the rainy season (summer and autumn), Samambaia Lake shows its maximal depth of around three meters, with macrophytes predominantly of the genus Nymphaea located in specific areas (Figure 3).

According to Souza et al. (2004), the regional vegetation encompasses sub-mountainous semi-deciduous seasonal 
forest, riparian forest, wetland vegetation and palms. Campos \& Souza (1997) consider this region as a transition between sub-mountainous semi-deciduous seasonal forest and cerrado (Brazilian savanna). The forest area has been recently removed for pasture and agricultural developments, leaving some isolated trees as remnants of the ancient forest. Campos \& Souza (1997) believe that the savanna predated the present forest vegetation and persists as enclaves in those environments where the forest species have failed to develop. The vegetation around the lake was largely altered and today consists mainly of "artificial" pasture and palm groves.

With the aim of detailing the previously reported paleoclimatic changes, sediments were evaluated from two vibrocore samples obtained from Lake Samambaia (2236' S/ $53^{\circ} 23^{\prime} \mathrm{W}$, municipality of Taquarussu/MS) within the Taquarussu Geomorphological Unit. The initial analyses indicated the presence of abundant spicules of freshwater sponges in the sediments.

Given the existing literature in which freshwater sponge spicules have been used in paleoenvironmental and paleolimnological reconstructions, it was decided to adopt them as paleoindicators. That way, hydrological and environmental alterations which occurred during the Holocene and Pleistocene were determined, confirming the presence of paleodrainage in the Taquarussu Region accordingly to a hypothesis previously put forth by Popolizio (1982), Justus et al. (1985), Stevaux (1994) and Pires Neto et al. (1994). The study also confirms the proposed periods of drier climate in the region during the Mid-Holocene (Stevaux 1994, 2000; Kramer \& Stevaux, 2001; Parolin \& Stevaux 2001, 2006; Parolin et al., 2007).

\section{METHODS}

The cartographic survey used the geomorphological map in Stevaux (2000), the aerial photographs at 1:60,000 from a flight made in 1996 and the topographical charts of Loanda (sheets SF-22-Y-A-V and SF 22-Y-A) at 1:100,000 and 1:250,000. Depth surveys were carried out in Samambaia Lake with the aid of a ruler and a global positioning system unit.

Cores from two points of Samambaia Lake (Figure 2) were obtained by vibrocore processing. Seven dates were obtained using thermoluminescence in accordance with the additional doses method (Ionic Crystals Laboratory, Dating and Fine Films/USP).

Twenty-one granulometric analyses were carried out using the sieve and pipet method, while following the classification proposed by Wentworth (1922) (GEMA Laboratory/Maringá State University). The percentage of organic matter was determined in twenty-two samples (eleven from each core), by burning one gram of the sediment for three hours at $550^{\circ} \mathrm{C}$ in a muffle furnace.

Three sampling campaigns were carried out to investigate the currently existing sponge fauna and the presence of spicules in the sediments. All kinds of submerged parts of macrophyte stands in the lake were pulled out and searched for encrusting sponges.

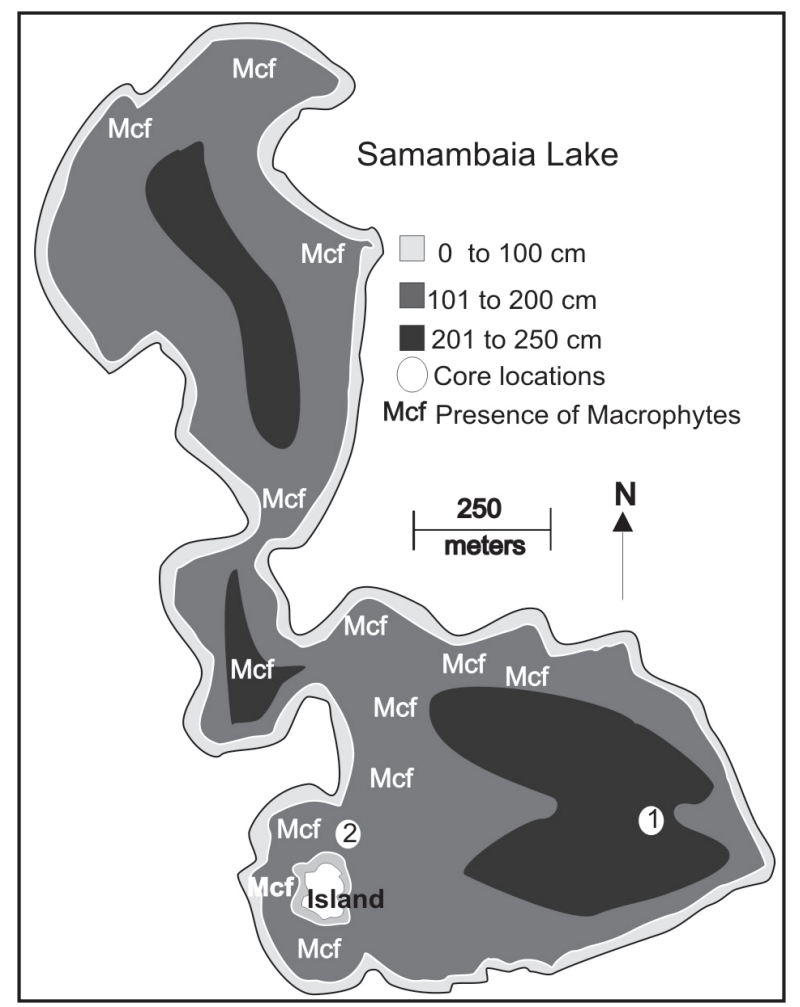

Figure 2. Samambaia Lake. Map indicating the sample points, depth curves and location of the macrophyte stands.

In order to carry out the taxonomic identification of the sponge spicules under a light microscope, portions of all sedimentary sections in the cored sediments were removed, boiled in an assay tube with nitric acid (65\%), washed several times with tap water and ultimately suspended in alcohol $(70 \%)$. Centrifugation was used to speed up the process. The material was dripped onto slides and, once dried, covered with Entelan ${ }^{\circledR}$ and coverslipped (Volkmer-Ribeiro \& Turcq, 1996). Microphotographs were obtained of all kinds of spicules found in the slides. The representative slides are catalogued in the Porifera collection of Museu de Ciências Naturais of Fundação Zoobotânica do Rio Grande do Sul, Porto Alegre (MCN-POR 6019 to MCN-POR 6025).

The spicule categories adopted follow Volkmer-Ribeiro \& Pauls (2000) and comprise the megascleres, spicules which integrate the skeletal frame and are generally the largest ones, the microscleres, smaller ones placed at the sponge surface and the gemmoscleres, spicules which cover the gemmules of fresh water sponges and constitute, with the microscleres, the most important morphological feature in the characterization of families, genera and species of freshwater sponges.

\section{Dating}

\section{RESULTS}

TL datings (Figure 4) indicate ages between the end of the Pleistocene and the Holocene: i) sediment core 1: 17,600 \pm 880 years $\mathrm{BP}(181 \mathrm{~cm}), 4,600 \pm 230$ years $\mathrm{BP}(132 \mathrm{~cm})$ and $4,350 \pm 210$ years BP $(94 \mathrm{~cm})$ and ii) sediment core $2: 32,740 \pm$ 1,630 years BP $(248 \mathrm{~cm}), 25,980 \pm 1,290$ years BP $(210 \mathrm{~cm}), 8,700$ \pm 430 years $\mathrm{BP}(168 \mathrm{~cm})$ and $5,600 \pm 280$ years BP $(75 \mathrm{~cm})$. 


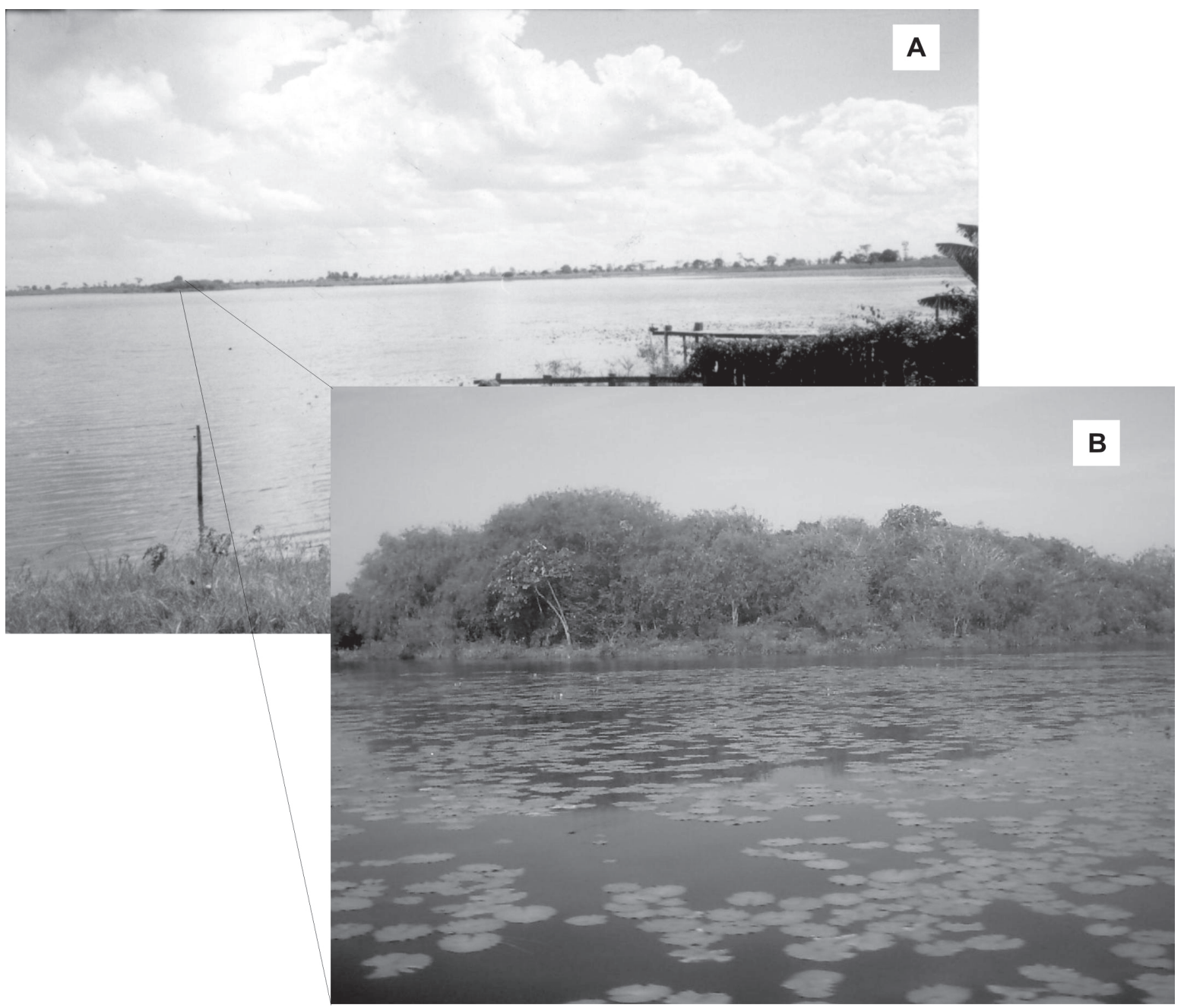

Figure 3. A partial view of Samambaia Lake (A) and detail of Nymphaea stands (B) along the edge of the island (photo by M. Parolin).

\section{Granulometry}

In probe 2, there was a predominance of fine and very fine sand with greater development of the fine fraction (silt and clay) from a depth of $165 \mathrm{~cm}$ towards the suface. In probe 1 , there was a predominance of fine and very fine sand between 88 and $132 \mathrm{~cm}$ of depth, and the fine fraction (silt and clay) was larger from 0 to $80 \mathrm{~cm}$ and 150 to $192 \mathrm{~cm}$ depth. The cumulative frequency of the granulometry for probe 2 showed increased clay content towards the base and two sequences of fine sand (top and base), intercalated by a sandier sequence (Figure 5).

\section{Organic matter}

The percentages of organic matter varied between 0.1 and $16 \%$ in probe 1 , with the highest values at the top and at $149 \mathrm{~cm}$ in depth (6.8\%). In probe 2 , the values were between 0.2 and $10 \%$, again with an increase towards the top. Of particular note is the presence of more significant values in the middle of the profile at $90 \mathrm{~cm}$ in depth $(6.1 \%)$ and close to the base at $228 \mathrm{~cm}$ in depth (5.8\%) (Figure 5).

\section{Sponge spicules}

Spicules of the following freshwater sponge species were detected in the sediments studied: Metania spinata (Carter, 1881), Radiospongilla amazonensis Volkmer-Ribeiro \& Maciel, 1983, Dosilia pydanieli Volkmer-Ribeiro 1992, Heterorotula fistula Volkmer-Ribeiro \& Motta, 1995, Corvospongilla sp. and Oncosclera sp. The first four species compose a freshwater sponge assemblage characteristic of peat bog ponds within the Cerrado biome (Volkmer-Ribeiro 1992, Volkmer-Ribeiro \& Motta, 1995). On the other hand, species of genera Corvospongilla and Oncosclera are almost exclusive dwellers of the rocky substrates of large South American rivers (Volkmer-Ribeiro \& Pauls, 2000; Batista \& Volkmer-Ribeiro, 2002; Batista et al. 2003). All such species have their spicular sets (megascleres, microscleres and gemmoscleres) illustrated in the above-cited papers. A clear distinction can be perceived with respect to silica uptake between spicules pertaining to the lentic and lotic habitats detected, where the first ones are thinner and fragile while the second ones are robust and stout, indicating in the latter a greater and more constant supply of $\mathrm{SiO}_{2}$ from running bottom waters as would be expected.

The present sediments of Lake Samambaia contained few megascleres of M. spinata and of $R$. amazonensis in spite of the fact that no current sponges were found living in the lake. 


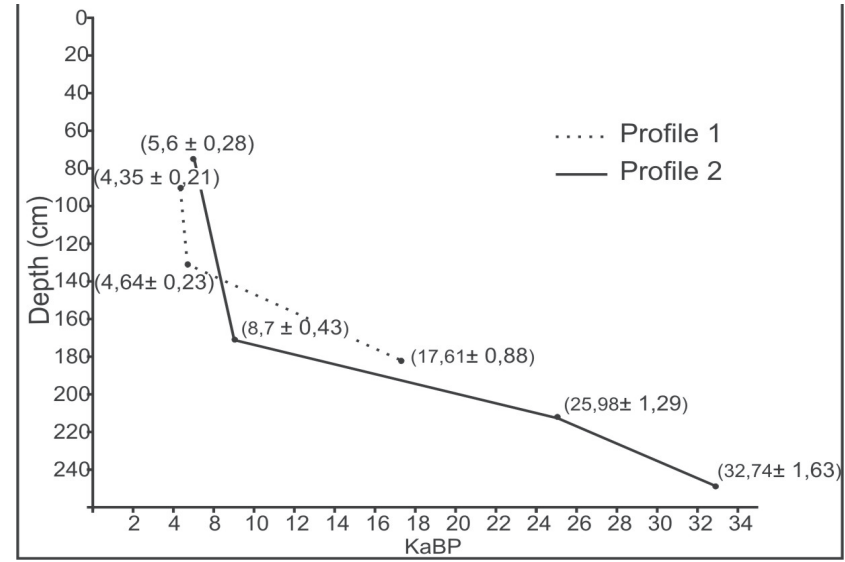

Figure 4. Samambaia Lake. Results of the thermoluminescence dating on both assessed profiles.

The analyses regarding the sponge spicules in probe 1 (Figure 6) revealed three generating phases: phase I- 192 to 150 and 133 to $122 \mathrm{~cm}$ with rare spicule fragments; phase II$94 \mathrm{~cm}$ with fragments of megascleres of Corvospongilla sp.; phase III- 88 to $70 \mathrm{~cm}$ with abundant spicular material allowing for the identification of Metania spinata (megascleres, greater presence between 70 to $0 \mathrm{~cm}$ ); Dosilia pydanieli (gemmoscleres, greater presence between 88 to $70 \mathrm{~cm}$ ) and Heterorotula fistula (fragments of the longer gemmosclere) (Figure 6).

In probe 2 (Figure 7), the analyses reveal the presence of five generating phases: phase I- 248 to $230 \mathrm{~cm}$, without spicule fragments; phase II-214 to 190 and 170 to $140 \mathrm{~cm}$, fragments of sponge spicules increasing in quantity from the base towards the top, Corvospongilla sp. and Oncosclera sp.; phase III-spicules are extremely abundant in the sediment, with predominance of $D$. pydanieli (microscleres and gemmosclere fragments) and Metania spinata (fragments of beta megascleres); phase IV-125 to $70 \mathrm{~cm}$, spicule fragments and entire megascleres of Corvospongilla sp.; phase V- 60 to $0 \mathrm{~cm}$, spicules are again extremely abundant in the sediment, with $M$. spinata (beta megascleres) appearing with increased abundance from the base to the top and in fewer number Radiospongilla amazonensis (megascleres).

In probe 1 , the sequences with a weak spicule density were 192 to 150,133 to 122 and $94 \mathrm{~cm}$, and in probe 2, these were 214 to 190,170 to 140 and 125 to $70 \mathrm{~cm}$.

\section{DISCUSSION}

The seven datings show similarities with the ages obtained by thermoluminescence in lakes located in the same geomorphologic unit, and very close to Samambaia Lake. Parolin (2006) found for "Linda" and "Dos 32" lakes the following ages: a) "Linda" lake - 18,760 years BP $(81 \mathrm{~cm})$, 24,600 years BP $(131 \mathrm{~cm})$ and 26,300 years BP $(195 \mathrm{~cm})$; b) “Dos 32" lake - 10,200 years BP (23 cm), 19,700 years BP (93 $\mathrm{cm})$ and 22,200 years BP $(140 \mathrm{~cm})$. Kramer \& Stevaux (2001) indicate for "Piranha" lake the following ages: 2,200 years BP $(8 \mathrm{~cm}), 3,390$ years BP $(12 \mathrm{~cm}), 12,480$ years BP $(18 \mathrm{~cm})$ and 16,640 years $\mathrm{BP}(38 \mathrm{~cm})$.
A temporal hiatus of 12,970 years between the dates 4,640 and 17,610 years BP in probe 1, and of 17,280 years between 8,700 and 25,980 years BP in probe 2 (Figure 4) can be established. Recent studies, carried out by Kramer \& Stevaux (2001), Stevaux (2000) and Parolin \& Stevaux (2001, 2004, 2006) in the region of Taquarussu (MS) have established a temporal hiatus of approximately 9,000 years BP (defined between 3,000 and 12,000 years BP) with intense eolic/wind activity at around 3,000 years BP. Based on the datings, it is also possible to determine the existence of a rapid process of deposition and sedimentation in probe 1 (around $0.35 \mathrm{~mm} /$ year-1) between 4,640 and 4,360 years BP. Similar sedimentation was also recorded for the period from 4,610 to 4,010 years BP $(1.6 \mathrm{~mm} /$ year- 1$)$ in peaty sediments from the Fazenda Boa Vista Unit in the region of Taquarussu/MS (Parolin et al., 2007).

When studying the granulometric curves from the twentyone samples belonging to the two cores, we arrived at the conclusion that the finest sequences (silt and clay), located at the base of the profiles (Figure 5), must be related to the formation of the lake over an ancient area, where the alluvial processes of the clays acted over an extensive period of time during which the terrace was formed. This granulometric condition would seem to correspond with the data obtained at the Taquarussu Geomorphological Unit by Stevaux (1994, 2000) and Kramer \& Stevaux (2001). The spicules are present in practically all the assessed profiles regardless of the granulometric results. Spongofacies occurred in both situations of increased presence of clay, and fine and very fine sand (silt). Therefore, granulometry did not help in distinguishing lotic from lentic environments, which may be explained by the fact that the area in question is a flat floodplain where the capacity of the waters to transport coarser materials is very reduced.

In the two probes, there is an increase in the percentage of organic matter in sequences with ages between 5,600 and 4,640 years BP (Figure 4), suggesting a more humid phase in this period. In addition to that, a gradual increase was found in these percentages towards the top, which would be consistent with the first humid event and the current more humid phase, described by Stevaux $(1994,2000)$. The increase in percentage of organic matter towards the top of these two profiles evidence the lake stabilization process under the extant weather conditions, allowing for the accumulation of organic matter. Frost $(1978,1981$,$) demonstrated a positive$ relationship between organic matter and the production of sponges. In the present case, this relationship is evidenced by the greater amount of spicules in the sediments. In the case of the columns studied (profiles), the apparent lack of agreement of this relationship at greater depths (Figure 5) must be primordially related to the lotic phases discussed herein, which did not contribute to the accumulation of organic matter. Studies by Kramer \& Stevaux (2001) at Piranha Lake (Taquarussu Geomorphological Unit), offer two pieces of evidence of a more humid phase at 6,000 years BP, represented by an intense ferruginous-clay cementation and a paleolevel. Normally, the "optimum" climate of the Holocene 

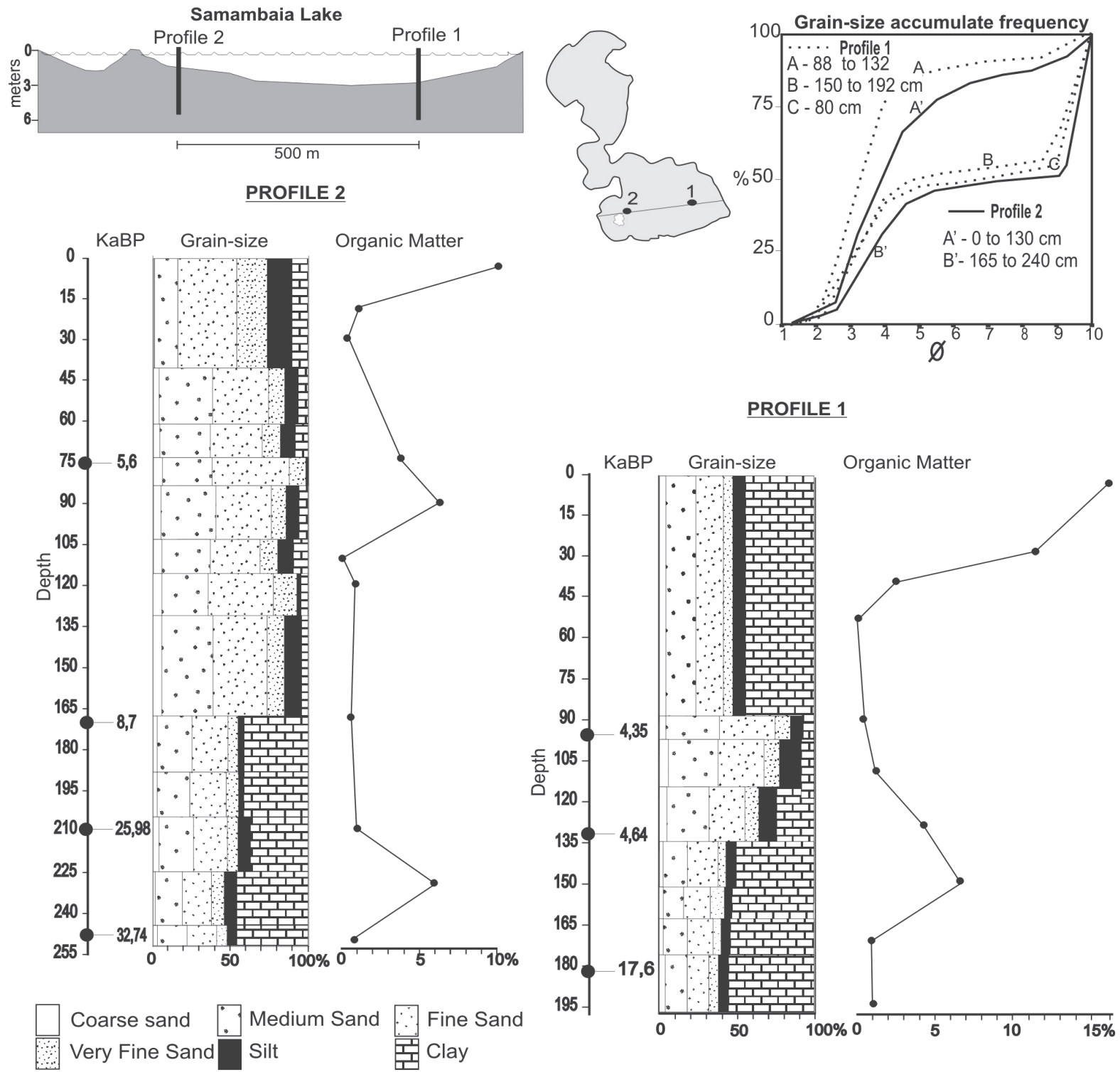

Figure 5. Topographical profile and map showing the core sampling points at Samambaia Lake and the results by probe: Granulometry; datings (TL) and organic matter (\%).

in South America and Brazil has been accepted to be at around 5,000 years BP, with evidence of increased precipitation lying on the increased levels of the lakes, reestablishment of forest belts and the construction of floodplains along the main rivers (Margraf, 1989). Significant changes in the hydrology of the Paraná River dated at around 8,000 years BP, using C14 , indicate a vertical cut of the channel and the consequent formation of a terrace around ten meters high (Stevaux \& Santos, 1998). Iriondo \& Garcia (1993), writing on the climatic variations in Northeast Argentina, suggest that the first humid event started between 7,500 and 8,000 years BP, with the lower limit being defined at 3,500 years BP.

The fragments of sponge spicules situated at 32,740 and 25,980 years BP in probe 2 (Figure 7) and 17,600 years BP in probe 1 (Figure 6) are indicative of periods with very little permanent water and/or no water, pointing to a drier phase than the present one. According to Suguio (1999), a drier phase began between 31,000 and 28,000 years BP, represented mainly in the northern hemisphere, by the last ice age. During this same epoch, dry periods are reported to have occurred in Central Brazil according to Salgado-Laboriau (2001) who, by means of palynology, found evidence of savanna with few trees, extensive grass and shrub coverage, woods with elements from colder climates, the absence of swamps, but abundant aquatic plants in marshes. Studies carried out by Riccomini et al. (1991), in Cratera Colônia (SP), indicate that a drastic reduction of the forest, swamp and peaty elements occurred, coinciding with a large increase in open field elements, suggesting a significant climatic change with colder semi-arid conditions persisting until 18,180 years BP. Landscapes devoid of vegetation and indicative of drier cooler climates are reported between 30,000 and 18,000 years BP by Behling \& Litchte (1997) in Morro de Itapeva (SP) and Lagoa do Pires (MG), as well as in Botucatu (SP) (Behling et al., 1998). 


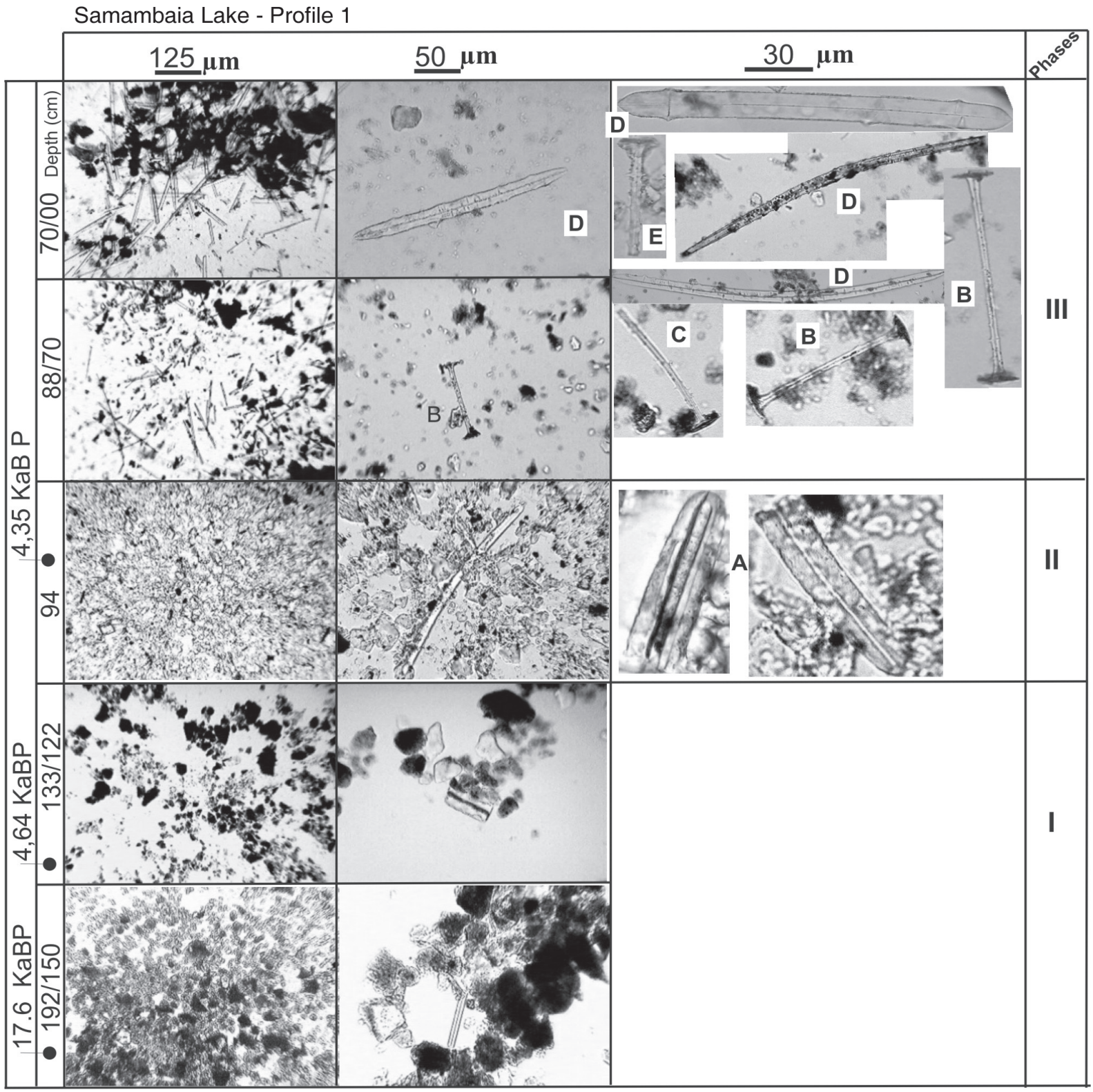

Figure 6. Samambaia Lake. Probe one. Photograph of the sediment profile as seen in the slides prepared for the detection of sponge spicules with the optical microscope: A, fragment of a megasclere of Corvospongilla sp.; B, gemmosclere of Dosilia pydanieli; C, fragment of a gemmosclere of Dosilia pydanieli; D, beta megasclere of Metania spinata; E, fragment of the longer gemmosclere of Heterorotula fistula (photo by M. Parolin).

For the Amazon region (Serra dos Carajás), Sifeddine et al. (1994) found drier phases prevailing at 28,000 years BP.

In probe 2, between 25,980 and 8,700 years BP (Figure 7), there are fragments of sponge spicules of Corvospongilla sp. and Oncosclera sp., both genera indicative of lotic rocky substrates, demonstrating the existence of lotic environments, (Volkmer-Ribeiro \& Pauls, 2000). Likewise spicules of the genus Oncosclera, have been generally recorded for rivers with rocky substrates: Bonetto \& Ezcurra de Drago (1970) for the Paraná River, the Iguaçu River and the Uruguay River in the northern part of Argentina; Batista \& Volkmer-Ribeiro (2002) for the upper reaches of Paraná River (Goiás) and Paraguay River (Mato Grosso); and Batista et al. (2003) for rivers of Central Amazonia. On the other hand,
Batista et al. (2003) recorded the occurrence of Corvospongilla seckti occupying rocky substrates as well as submerged trunks and branches along the banks and beds in the rivers of the Amazon region, whilst Bonetto \& Ezcurra de Drago (1970) reported the occurrence of the species in rocky river substrates in northern Argentina.

Popolizio (1982), Justus et al. (1985), Pires Neto et al. (1994) and Stevaux (1994) argue for the existence of paleodrainage in the region. The presence of Corvospongilla sp. and Oncosclera sp. confirm this hypothesis, indicating that this ancient drainage was established at the end of the Pleistocene around 25,980 years BP and probably remained active until around 8,700 years $B P$.

Between 8,700 and 5,600 years BP (Figure 7), there is a 


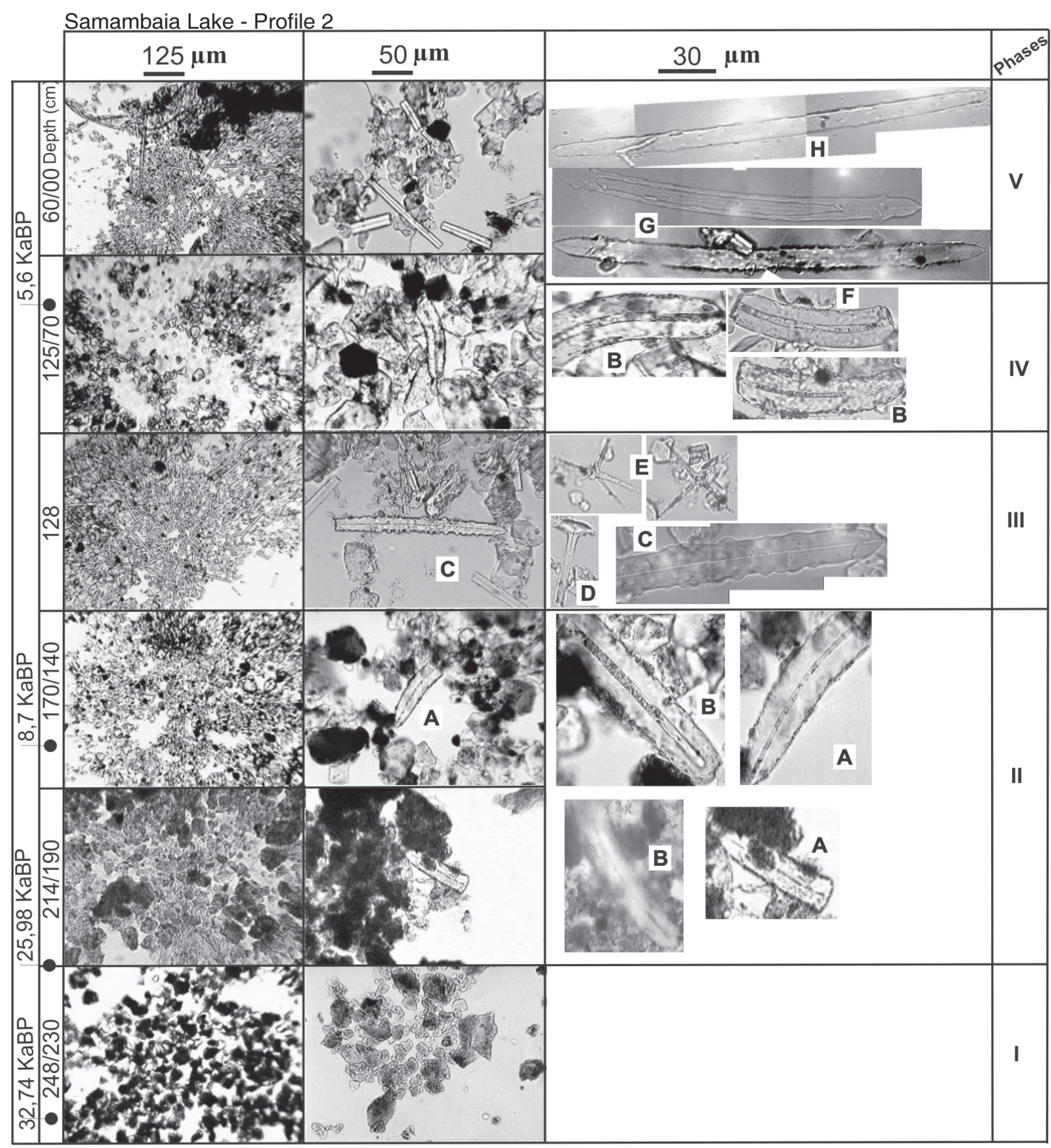

Figure 7. Samambaia Lake. Probe two. Photograph of the sediment profile as seen in the slides prepared for the detection of sponge spicules with the optical microscope: A, Fragment of megasclere of Oncosclera sp.; B, fragment of a megasclere of Corvospongilla sp.; C, fragment of a megasclere of Metania spinata; D, fragment of a gemmosclere of Dosilia pydanieli; $\mathbf{E}$, microsclere of Dosilia pydanieli; $\mathbf{F}$, fragment of a megasclere from a lotic environment, undetermined species; $\mathbf{G}$, beta megasclere from Metania spinata; $\mathbf{H}$, megasclere from Radiospongilla amazonensis (photo by M. Parolin).

transition from lotic to a lentic environment. The lentic phase is well characterized by the abundant deposit of sponge spicules from mainly two species identified based on the presence of the microscleres and gemmoscleres of $D$. pydanieli and fragments of beta megascleres of $M$. spinata. The bulk of the deposit consists of the larger skeletal spicules (megascleres) of these two species. Both species are reported to occur from Roraima to São Paulo states, in small lakes or ponds typical of the savanna biome, with abundant macrophytic vegetation, encrusting stalks and submerged leaves (Volkmer-Ribeiro, 1992). With the aim of defining such biomineral deposits in which sponge spicules predominate allowing for the identification of species and the prevailing past habitat conditions, the term "spongofacies" is now proposed (Figure 8).

When analyzing lacustrine sediments from the Paranaíba region (MS), Volkmer-Ribeiro \& Motta (1995) identified $M$. spinata as the predominant species occurring in abundance from the base to the top of the deposits and D. pydanieli as a species indicative of the middle to the last phases of the pond depositional processes. Both species tolerate environments with slightly acid water, abundant macrophytes and seasonal exposure to drought when abundant gemmules are produced. The absence of gemmoscleres of the two species in probe $2(128 \mathrm{~cm}$; Figure 7$)$, indicate that both species benefited from permanent immersion, with little fluctuation of the lake level during this period. Advantage was then taken 




Figure 8. Samambaia Lake. Spongofacies seen in probes 1 and 2, and their respective depths.

of the permanent availability of dissolved silicon to build up the skeleton instead of gemmule production.

At 4,350 years BP in probe 1 (Figure 6) and 5,600 years BP in probe 2 (Figure 7), fragments of megascleres of Corvospongilla sp. again indicate the presence of a lotic environment. After 4,350 years BP, between depths of 88 and $70 \mathrm{~cm}$ in probe 1 (Figure 5), there is again the recording of a spongofacies represented exclusively by complete or fragmented gemmoscleres of $D$. pydanieli. This situation indicates the fixation/permanence of a lentic environment, subjected to constant fluctuations in the water level, probably with long periods of drought. This drier condition in the MidHolocene is reported in various studies in the region (Stevaux 1994, 2000; Kramer \& Stevaux 2001; Parolin \& Stevaux 2001, 2004, 2006; Parolin et al. 2006, 2007).

In the sequences from the top of probe $1(70$ and $0 \mathrm{~cm})$ and from probe $2(60$ and $0 \mathrm{~cm}$ ), (Figure 6 and 7), spongofacies are detected with large amounts of whole and well-developed beta megascleres of $M$. spinata and in smaller numbers megascleres of $R$. amazonensis together with the appearance of fragments of the long gemmosclere of $\mathrm{H}$. fistula. These data point to a long period of water supply in relation to the sequences hereto described. $R$. amazonensis inhabits seasonal lakes, and to date, it has been recorded in Central Brazil and Amazonia (Volkmer-Ribeiro 1992; Volkmer-Ribeiro et al., 1998, 1995; Cândido et al., 2000). H. fistula has only been recorded in the composition of the spongillite deposits in lakes in Southeast Brazil (Volkmer-Ribeiro \& Motta 1995).
Farmers of the region report that during periods of prolonged rain input, Samambaia Lake becomes linked to other neighboring ponds giving way to a large semi-lotic system flowing towards the Ivinhema River, though such phases would be episodic and short-lived probably preventing the formation of sponges characteristic of lotic environments. The spicules found in the cores, mainly those indicative of the lentic environment, suggest that those sponges had good conditions for development, confirming, without doubt, their occurrence in situ during the Holocene. According to Fortes et al. (2005), the Ivinhema River underwent significant hydrological alterations in its lower course due to tectonic activity at around 5,000 years BP. Such an activity could explain the paleodrainage identified.

The absence of sponges currently living in the lake may be linked to its present higher depth which limits the occurrence of the macrophytic vegetation and thus the available substrates. Indeed, the present depth of the lake waters favors the occurrence of the genus Nymphaea, with quite long slim and sticky stems which do not favor sponge encrusting.

\section{CONCLUSIONS}

The use of freshwater sponge spicules as proxy data allowed the determination of three significant environmental and hydrological phases linked to the evolution of the Parana River hydrological system in the Taquarussú Region, Brazil, at the end of the Pleistocene and in the Holocene: a) phases 
where sponge spicules were absent indicating very little or no water and reduced organic matter in the sediments, at around 32,740 and 17,600 years BP; b) fluvial phases indicated by spicules of river dwelling sponges around $25,980,8,700$, 5,600 and 4,350 years BP and c) lacustrine phases with increased organic matter, between 8,700 and 5,600 years BP and after 4,360 years BP until the present indicated by spicules of sponges characteristic of Cerrado peat bog ponds.

The long-held hypotheses regarding paleodrainage in the region were in need of confirmation, partly due to the disregard of previously detected evidence, i.e., rich deposits of sponge spicules. These are now used as bio-indicators, confirming their importance in paleoenvironmental reconstructions.

\section{ACKNOWLEDGMENTS}

The authors thank CAPES (MP), CNPq (CVR, JCS) and the following people: H. Stein, owner of the Fazenda Samambaia for his kind assistance with the fieldwork; V. S. Machado (MCN-FZBRS), for the processing of the spicules slides; M. de Moraes (GEMA/UEM) for the sedimentological analysis; and V. Alves, J.A. da Rocha, L. P. de Souza, O.J. Tomaz, J. Marmontel and J.C. Rodrigues for help with the fieldwork. This paper was improved and enriched thanks to the valuable suggestions offered by the two referees, $\mathrm{M}$. McGlue and A.F. Zucol.

\section{REFERENCES}

Batista, T.C.A. \& Volkmer-Ribeiro, C. 2002. Comunidades de esponjas do curso superior dos rios Paraná (Goiás) e Paraguai (Mato Grosso), Brasil, com redescrição de Oncosclera schubarti (Bonetto and Ezcurra de Drago). Revista Brasileira de Zoologia, 19:123-136.

Batista, T.C.A.; Volkmer-Ribeiro, C.; Darwich, C. \& Alves, L. F. 2003. Freshwater sponges as indicators of floodplain lake environments and of river rocky bottom in Central Amazônia. Amazoniana, 18:525-549.

Behling, H. \& Lichte, M. 1997. Evidence of dry and cold climatic conditions at glacial times in tropical southeastern Brazil. Quaternary Reseach, 48:348-358.

Behling, H.; Lichte, M. \& Miklos, A.W. 1998. Evidence of a forest free landscape under dry and cold climatic conditions during the last glacial maximum in the Botocatu region (São Paulo State), Southeaste Brazil. Quaternary of south America and Antartic Peninsula, 11:99-110.

Bertoldi de Pomar, H. 1970. Fitolitos y zoolitos: su significado geologico en sedimentos continetales. Boletin de la Asociación Geológica de Córdoba, 1:21-31.

Bertoldi de Pomar, H. 1972. Ópalo organógeno en sedimentos superficiales de la llanura santafesina. Ameghiniana, 9:265-279.

Bertoldi de Pomar, H. 1975. Los silicobiolitos: sinopsis de su conocimento. Darwiniana, 19:173-206.

Bonetto, A.A. \& Ezcurra de Drago, I. 1970. Esponjas de los afluentes del Alto Parana en la Provincia de Misiones. Acta Zoologica Lilloana, 27:37-58.

Bradley, R.S. 1985. Quaternary Paleoclimatology. Boston, Allen \& Unwin, $472 \mathrm{p}$.

Campos, J.B. \& Souza, M.C. 1997. Vegetação. In: A.E.A. Vazzoler;
A.A. Agostinho \& N.S. Hahn (eds.) A Planície de Inundação do Alto Rio Paraná - Aspectos físicos, biológicos e socioeconômicos. Editora da Universidade de Maringá, p. 331-342.

Cordeiro, R.C.; Turcq, B.; Suguio, K.; Volkmer-Ribeiro, C.; Silva, A.O.; Sifeddine, A. \& Martin, L. 1997. Holocene environmental changes in Carajás Region (Pará, Brazil) recorded by lacustrine deposits. Verh. International Verein. Limnology, 26:814-817.

Fortes, E.; Stevaux, J.C. \& Volkmer, S. 2005. Neotectonics and channel evolution of the Lower Ivinhema River: A right-bank tributary of the upper Paraná River, Brazil. Geomorphology, 70:325-338.

Frost, T.M. 1978. Impact of the freshwater sponge Spongilla lacustris on a Sphagnum bog-pon. Verh. International Verein. Limnology, 20:2368-2371.

Frost, T.M. 1981. Analysis of ingested particles within a freshwater sponge. Transactions of the American Microscopical Society, 100 (3):271-277.

Frost, T.M. 1991. Porifera. In: J.H. Thorp \& A.P. Covich (eds.) Ecology and classification of North American Freshwater Invertebrates, Academic Press, p. 95-124.

Gaiser, E.E.; Brooks, M.J.; Kenney, W.F.; Schelske, C.L. \& Taylor, B.E. 2004. Interpreting the Hydrological history of temporary ponds from chemical and microscopic characterization of siliceous microfossils. Journal of Paleolimnology, 1:63-76.

Hall, K.V. \& Herrmann, S. J. 1980. Paleolimnology of three species of fresh-water sponges (Porífera:Spongilidae) from a sediment core of a Colorado semidrainage mountain lake. Transactions of the American Microscopical Society, 99(1):93-100.

Harrison, F.W. 1988. Utilization of freshwater sponges in paleolimnological studies. Palaeogeography, Palaeoclimatology, Palaeoecology, 62:387-397.

Harrison, F.W. \& Warner, B.G. 1986. Fossil freshwater sponges (Porifera: Spongillidae) from Western Canada: An Overlooked Group of Quaternary Paleoecological Indicators. Transactions of the American Microscopical Society, 105:110-120.

Harrison, F.W.; Gleason, P. J. \& Stone, P.A. 1979. Paleolimnology of lake Okeechobee, Florida: an analysis utilizing spicular components of freshwater sponges (Porifera: Spongillidae). Notulae Naturae, 454:1-6.

Iriondo, M.H. \& Garcia, N.O. 1993. Climatic variations in the Argentine plains during last 18.000 years . Palaeogeography, Palaeoclimatology, Palaeoecology, 101:209-220.

Justus, J.O.; Brasil, A.E. \& Herrman, M.L. 1985. Projeto Geomorfologia. Rio de Janeiro, RADAM/BRASIL, Paranapanema (Folha SF 22).

Kramer, V.M.S. \& Stevaux, J.C. 2001. Mudanças climáticas na região de Taquaruçu (MS) durante o Holoceno. Boletim Paranaense de Geociencias, 49:79-89.

Margraf, V. 1989. Palaeoclimates in Central and South America since 18,000 BP base don pollen and lake-level records. Quaternary Science Reviews, 8:24-81.

Nimer, E. 1989. O Centro-Oeste na organização regional do Brasil. In: IBGE (ed.) Geografia do Brasil, p. 23-34.

Osterrieth, M. 2001. Silicobiolitos/silicofitolitos: su rol en la matriz de suelos y paleosuelos de ambientes costeros de Buenos Aires. In:ENCUENTRO ARGENTINO DE INVESTIGACIONES FITOLITICAS DEL CONO SUR, 2, 2001. Actas, Mar del Plata, p.13.

Parolin, M. 2006. Paleoambientes e paleoclimas no final do Pleistoceno e no Holoceno no sudeste do Estado do Mato Grosso do Sul. Programa de Pós-Graduação em Ecologia de Ambientes Aquáticos Continentais, Universidade Estadual de Maringá, Ph.D. Dissertation, $121 \mathrm{p}$. 
Parolin, M. \& Stevaux, J.C. 2001. Clima seco e formação de dunas eólicas durante o Holoceno Médio em Taquaruçu, Mato Grosso do Sul. Pesquisas em Geociências, 28:233-243.

Parolin, M. \& Stevaux, J.C. 2004. Eolian dunes in the Upper Paraná River: evidence of aridity during the Holocene. In: A.A. Agostinho; L. Rodrigues; L.C. Gomes; S. Thomaz; L. Miranda (eds.) Structure and functioning of the Paraná River and its floodplain, Editora da Universidade Estadual de Maringá, p.31-35.

Parolin, M. \& Stevaux, J.C. 2006. Dry climate and eolian dune formation in the Middle Holocene in Mato Grosso do Sul State, Center West Brazil. Zeistchrift für Geomorphologie, 145:177-190.

Parolin, M.; Medeanic, S. \& Stevaux, J.C. 2006. Registros palinológicos e mudanças ambientais durante o Holoceno de Taquarussu (MS). Revista Brasileira de Paleontologia, 9:137-148.

Parolin, M.; Volkmer-Ribeiro, C. \& Stevaux, J.C. 2007. Sponge spicules in peaty sediments as paleoenvironmental indicators of the Holocene in the upper Paraná river, Brazil. Revista Brasileira de Paleontologia, 10:17-26.

Penney, J.T. \& Racek, A.A. 1968. Comprehensive revision of a worldwide collection of freshwater sponges (Porifera: Spongillidae). Bulletin of the United States Natural Museum, 272:1-184.

Pires Neto, A.G.; Bartorelli, A. \& Vargas, M.S.1994. A planície do Rio Paraná. Boletim Paranaense de Geociências, 42:217-229.

Pisera, A. \& Sáez, A. 2003. Paleoenvironmental significance of a new species of freshwater sponge from the Late Miocene Quillagua Formation (N Chile). Journal of South American Earth Sciences, 15:847-852.

Popolizio, E. 1982. Geomorphology of the Argentina northeast. Water International, 7:161-177.

Racek, A.A. 1970. The Porifera. Transactions of the American Philosophical Society, 60:143-149.

Riccomini, C.; Turcq, B.; Martin, L.; Moreira, M.Z. \& Lorscheitter, M.L. 1991. The Colônia Astrobleme, Brasil. Revista do Instituto Geológico, 12:87-94.

Salgado-Laboriau, M.L. 2001, Reconstruindo as comunidades vegetais e o clima no passado. Humanidades, 48:24-40.

Sallun, A.E.M. 2007. Aloformação Paranavaí: Depósitos coluviais quaternários da bacia hidrográfica do alto rio Paraná. Programa de Pós-Graduação em Geologia Sedimentar, Universidade de São Paulo, Ph.D. Dissertation, 176 p.

Selley, R.C. 1970. Ancient Sedimentary Enviroments. Ithaca, Cornell University Press, $237 \mathrm{p}$.

Sifeddine, A.; Martin, L.; Turcq, B.; Volkmer-Ribeiro, C.; Soubies, F.; Cordeiro, R.C. \& Suguio, K. 2001. Variations of the amazonian rainforest environment: a sedimentological record covering 30,000 years BP. Palaeogeography, Palaeoclimatology, Palaeoecology, 168:221-235.

Sifeddine, A.; Frohlich, F.; Fournier, M.; Martin, L.; Servant, M.; Soubiès, F.; Turcq, B.; Suguio K. \& Volkmer-Ribeiro, C. 1994. La sedimentation lacustre indicateur de changements des paleoenvironments aucours dos 300.000 dernières années Carajás Amazonie, Brésil. Academie des Sciences, 2(318):1645-652.

Souza, M.C.; Kazue, K.K.; Romagnolo, M.B.; Tomazini, V.; Albuquerque, E.C.; Secorun, A.C. \& Miola, K.T.B. 2004. Riparian vegetation of the upper Paraná River floodplain, Paraná and Mato Grosso do Sul State, Brazil. In: A.A. Agostinho; L. Rodrigues; L.C. Gomes; S.M. Thomaz \& L.E. Miranda (eds.)
Structure and functioning of the Parana River and its floodplain, Editora da Universidade Estadual de Maringá, p. 233-238.

Stevaux, J. C. 1986. Faciologia e ambientes de sedimentação da formação Rio Bonito da Bacia do Paraná. Programa de PósGraduação em Geologia Sedimentar, Universidade de São Paulo, Master thesis, $45 \mathrm{p}$.

Stevaux, J.C. 1994. Upper Paraná River (Brazil) geomorphology and paleoclimatology. Quaternary International, 21:143-161.

Stevaux, J.C. 2000. Climatic events during the Late Pleistocene and Holocene in the Upper Paraná River: correlation with NE Argentina and South-Central Brazil. Quaternary International,72:73-85.

Stevaux, J.C. \& Santos M.L. 1998. Paleohydrological changes in the upper Paraná River (Brazil) during the Late Quaternary: a faciological approach. Paleohydrology and Hydrological Science, 1:273-285.

Suguio, K. 1999. Geologia do Quaternário e Mudanças AmbientaisPassado + Presente $=$ Futuro? São Paulo, Paulo's Editora, 366p.

Volkmer-Ribeiro, C. 1992. The freshwater sponges in some peatbog ponds in Brazil. Amazoniana, 12:317-335.

Volkmer-Ribeiro, C. 2007. South American continental sponges: state of the art of the research. In: M.R. Custódio; G. LôboHajdu G.; E. Hajdu \& G. Muricy (eds.) Porifera research: biodiversity, innovation and sustainability. MNRJ, p. 117-121.

Volkmer-Ribeiro, C. \& Motta, J.F.M. 1995. Esponjas formadoras de espongilitos em lagoas no triângulo mineiro e adjacências, com indicação de preservação de habitat. Biociências, 2:145-169.

Volkmer-Ribeiro, C. \& Pauls, S.M. 2000. Esponjas de agua dulce (Porifera, Demospongiae) de Venezuela. Acta Biologica Venezuelica, 20(1):1-28.

Volkmer-Ribeiro, C. \& Turcq, B. 1996. SEM analysis of silicious spicules of a freshwater sponge indicate paleoenvironmental changes. Acta Microscópica, 5:186-187.

Volkmer-Ribeiro, C.; Motta, J.F.M. \& Callegaro, V.L. 1995. Taxonomy and distribution of Brazilian Spongillites. In: Y. Watanabe \& N. Fusetani (eds.) Sponge Sciences: Multidisciplinary perspectives, Springer Verlag, p.271-278.

Volkmer-Ribeiro, C.; Mansur, M.C.D.; Mera, P.A.S. \& Ross, S.M. 1998. Biological Indicators in the Aquatic Habitats of the Ilha de Maracá. In: W. Milliken \& J. Ratter (eds.) Maracá: the biodiversity and environment of an Amazonian rainforest. Chichester, Jonh Wiley \& Sons, p. 403-414.

Volkmer-Ribeiro, C.; Correia, M.F.; Brenha, S.L.A. \& Mendonça, M.A. 1999. Freshwater sponges from a Neotropical Sand Dune area. Memoirs of the Queensland Museum, 44:643-649.

Volkmer-Ribeiro, C.; Marques, D.M.; De Rosa-Barbosa, R. \& Machado, V.S. 2006. Sponge spicules in sediments indicate evolution of coastal freshwater bodies. Journal of Coastal Research, 39:469-472.

Volkmer-Ribeiro, C.; Ezcurra de Drago, I \& Parolin, M. 2007. Spicules of the freshwater sponge Ephydatia facunda indicate lagoonal paleoenvironment at the Pampas of Buenos Aires Province, Argentina. Journal of Coastal Research, 50:449-452.

Wentworth, C.K. 1922. A scale of grade and class terms for clastic sediments. Journal of Geology, 30:377-392.

Zucol, A.F.; Brea M. \& Scopel A. 2005. First record of fossil wood and phytoliths assemblages of the Upper Pleistocene in El Palmar National Park (Argentina). Journal of South American Earth Sciences, 20(1-2):33-43. 